Dergi Ana Sayfası: https://dergipark.org.tr/tr/pub/ahbvtfd

ISSN: $2687-1912$

DOI: $10.34189 / \mathrm{tfd} .24 .01 .001$

\title{
Konaklama İşletmeleri Yöneticilerinin Bakış Açısından Dağıtım Kanallarında Yaşanan Çatışmalar: Antalya Bölgesi Örneği
}

(Conflicts In The Distribution Channels From The Perspective of Accommodation Establishments Managers: Example of Antalya Region)

\author{
Selda Güven EĞILLMEZGIL ${ }^{\mathrm{a}} \quad{ }^{*}$ Hacı Mehmet YILDIRIM ${ }^{\mathrm{b}} \quad$ Lütfi ATAYc $\quad$ Serkan TÜRKMEN ${ }^{\mathrm{d}}$ \\ ${ }^{a}$ Çanakkale Onsekiz Mart Üniversitesi, Ezine Meslek Yüksekokulu, Seyahat Turizm ve Eğlence Hizmetleri Bölümü, Çanakkale-Türkiye \\ (seldaegilmezgil@ comu.edu.tr) https://orcid.org/0000-0002-4931-7880

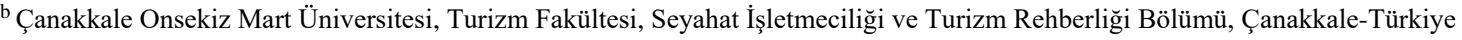 \\ (hadjimehmet@gmail.com) https://orcid.org/0000-0003-0718-7296 \\ ${ }^{c}$ Çanakkale Onsekiz Mart Üniversitesi, Turizm Fakültesi, Seyahat İ̧̧letmeciliği ve Turizm Rehberliği Bölümü, Çanakkale-Türkiye \\ (lutfiatay@yahoo.com) https://orcid.org/0000-0003-2598-6227 \\ ${ }^{\mathrm{d}}$ Çanakkale Onsekiz Mart Üniversitesi, Turizm Fakültesi, Seyahat İșletmeciliği ve Turizm Rehberliği Bölümü, Çanakkale-Türkiye \\ (serkanturkmen17@hotmail.com) https://orcid.org/0000-0002-0921-6102
}

MAKALE GEÇMIş̧i

Gönderim Tarihi:

16.09.2020

\section{Kabul Tarihi:}

08.12.2020

\begin{tabular}{l} 
Anahtar Kelimeler: \\
\hline Konaklama İşletmeleri \\
Seyahat Acentaları \\
Tur Operatörleri \\
Dağıtım Kanalları \\
Çatışma \\
\hline$\underline{\text { Keywords: }}$
\end{tabular}

Accommodation Establishments

Travel Agencies

Tour Operators

Distribution Channels

Conflict

Makalenin Türü: Araştırma Makalesi

*Sorumlu Yazar: Hacı Mehmet YILDIRIM E posta: hadjimehmet@gmail.com
$\ddot{O} \mathbf{Z}$

\begin{abstract}
Turizmin uluslararası boyutta olması ve farklı ülke pazarlarında bağlantı kurma gereksinimi, konaklama işletmelerinin tur operatörleri ve seyahat acentaları ile iş birliklerini zorunlu kılmaktadır. Turizm sektörünün önemli paydaşlarından olan bu işletmelerin iş birliği beraberinde çeşitli çatışmaları da ortaya çıkarmaktadır. $\mathrm{Bu}$ çalışmada Antalya bölgesinde faaliyet gösteren konaklama işletmelerinin, seyahat acentaları ve tur operatörlerine bağımlılık düzeylerinin belirlenmesi, operasyonlar sırasında yaşanan çatışmaları ve çatışmalara ilişkin çözümlerin tespit edilmesi amaçlanmaktadır. $\mathrm{Bu}$ amaçla, Antalya bölgesinde faaliyet gösteren konaklama işletmelerinde görev yapan 426 yöneticiye ulaşılmıştır. Elde edilen verilerle betimleyici analizler ve tek yönlü varyans analizi (ANOVA) yapılmıştır. Çalışma bulgularında, uzun süredir konaklama sektöründe faaliyet gösteren işletmelerin daha fazla pazarlık gücüne sahip olduğu, seyahat acentalarına verdikleri kontenjanlar ve acentalarla çalışma süreleri artıkça sözleşmeyi feshetme yönündeki girişimlerinin daha azaldığı sonuçlarına ulaşılmıştır.
\end{abstract}

\section{ABSTRACT}

Because of the need for international demand from different countries, accommodation businesses are forced to cooperate with tour operators and travel agencies. The cooperation of these enterprises, which are important stakeholders in the tourism sector, also reveals various conflicts. In this study, it is aimed to determine the level of dependency of accommodation businesses in Antalya destination on travel agencies and tour operators, and to determine the conflicts and its solutions. We reached 426 managers at accommodation establishments operating in the Antalya destination to collect data by the questionnaire forms. Descriptive analyzes and one-way analysis of variance (ANOVA) were performed on the data collected. In the findings of the study, it was concluded that accommodation businesses operating in the for a long time in tourism sector have more bargaining power, and as the quotas they give to travel agencies and their working duration with agencies increase, their attempts to terminate the contract decrease.

Makalenin Künyesi: Eğilmezgil, S. G., Ylldırım, H. M., Atay, L. \& Türkmen, S. (2021). Konaklama İşletmeleri Yöneticilerinin Bakış Açısından Dağıtım Kanallarında Yaşanan Çatısmalar: Antalya Bölgesi Örneği. AHBVÜ Turizm Fakültesi Dergisi, 24 (1), 1-19. 


\section{GíRiş}

Turizm; iş birliğinin yoğun olduğu bir sektördür ve herhangi bir turizm işletmesinin rekabet yeteneği genellikle yarattığ değer ve bu değeri tüketiciye ulaştıran diğer işletmelerle ilgilidir (Mwesiumo ve Halpern, 2016). Turizm işletmeleri, karlılıklarını artırmak için birbirini tamamlayan aktiviteler gerçekleştirirken, tedarikçiler, dağıtımcılar, hükümet ve diğer işletmelerle iş birliği içindedirler. (Guo ve He, 2012). Söz konusu işletmeler genellikler turistlerin ihtiyaçları etrafında organize olurlar ve taşıma, konaklama, eğlence programı ve etkinlikler, yeme- içme hizmeti, bilginin ulaştırılması ve dağıtım gibi çeşitli hizmetler şeklinde kategorize edilebilirler. Ana fonksiyonları turistlerin ihtiyaçların giderilmesi olan (Ford, Wang ve Vestal, 2012) dağıtım kanalları, turizmde hizmet sağlayıcılarla turistik tüketiciler arasında bağlantı kurmaktadır. Dağıtım kanallarında başarıyı sağlayabilmek adına etkili bir dağıtım sisteminin kurulması özellikle yoğun rekabet ortamında oldukça önemlidir. (Kracht ve Wang, 2010; Mirzayeva, Sarışık ve Ekber, 2016). Turizm işletmeleri, ürettikleri mal ve hizmetleri sadece işletmenin çevresinde değil, potansiyel turistleri hedef alarak planlamakta ve sunmaktadırlar. Oldukça geniş bir coğrafyaya yayılmış ve uzaklık faktörünün ana belirleyici olduğu turizm pazarında, turistik tüketicilere ulaşmak dağıtım kanallarında yer alan aracılar olmadan oldukça zahmetlidir (Hacıoğlu, 2014).

Teknolojik gelişmeler ve değişen müşteri tercihleri, dağıtım kanallarının çeşitliliğini arttırmıştır (Pearce, 2009). Oteller odalarını genellikle; kendi satış ekipleri, satış temsilcileri, katalog / kredi kartı ile ödeme formu, çağrı merkezi ve diğer kanallar aracılığıyla satmaktadır. Birden çok kanal kullanıldığında ve dağıtım yoğunluğu arttırıldığında, satıcı yeni ürün çeşidinin bir ölçüde mevcut ürünlerin satışının ve pazar payının yerini alması, kar miktarının azalması ve müşterinin yön değiştirmesi şeklinde birtakım tehditlerle karşı karşıya gelmektedir (Tan ve Dwyer, 2014). Turizmde, dağıtım diğer sektörlere göre çok daha önemlidir (Bastakis, Buhalis ve Butler, 2004) ve olumsuz ilişkiler nedeniyle şirketler arasında çatışmaların yaşanması oldukça sık rastlanılan bir durumdur (Mwesiumo ve Halpern, 2016). İlişkilerin ve bağlantıların kurulması, geliştirilmesi ve yönetilmesi beraberinde önemli zorlukları ortaya çıkartmaktadır (March ve Wilkinson, 2009). Ayrıca hangi dağıtım kanalının nasıl bir kombinasyonla kullanılacağı kararı da oldukça kritik ve risklidir (Pearce, 2009). Her geçen gün konaklama sektörü daha fazla rekabetçi ve daha karmaşık bir hal almakta (Tan ve Dwyer, 2014) ve muhalif ilişkiler oldukça yaygın (Zhang, Song ve Huang, 2009) bir biçimde 
ortaya çıkmaktadır. Turizm sektöründe var olan yoğun rekabet ortamı ise şirketleri daha çevik ve esnek olmaya zorlamakta, pazarda daha güçlü var olabilmek adına dağıtım aracılarıyla iş birliğini artırmayı gerekli kılmaktadır (Guo ve He, 2012).

Otellerin oda kapasitelerinin yüksek olması, pazarlama konusundaki yetersizlikler, talep dengesizliği, pazarlama ve işçilik maliyetlerinin yüksek olması gibi nedenler, işletmelerin daha düşük kar oranlarıyla tur operatörlerine ve seyahat acentalarına yönelmelerine neden olmaktadır. Turizm sektöründeki dağıtım kanallarında yer alan aracıların birbirlerine olan bağlılık düzeylerinin belirlenerek, dağıtım kanallarında yaşanan çatışmaların tespit edilmesi ve ilgili çözüm önerilerinin ortaya konulması açısından bu çalışma önem arz etmektedir.

\section{KAVRAMSAL ÇERÇEVE}

\subsection{Turizmde Dağıtım Kanalları}

Ekonomi bilimi dağıtımı; alışveriş maliyeti, rekabet gücüne göre yönetim, kanal performansı, pazarlık gücü, kar paylaşımı, pazarın farklılıkları, pazardaki konum, kanal çatışması ve farklı kültürlerin benzerliklerini temel alan küresel pazar stratejilerini dikkate alarak değerlendirmektedir (Stangl, Inversini ve Schegg, 2016). Dağıtım kanalı üyelerinin; fiziki mal, mülkiyet, tanıtım, pazarlık, finansman, risk, sipariş ve ödeme olmak üzere geçerli sekiz dolaşım fonksiyonunu tanımlanmaktadır (Pearce, 2008). İlk üç fonksiyon üreticiden tüketiciye doğru, sonraki üç fonksiyon her iki yönde ve son ikisi de tüketiciden üreticiye doğrudur. Söz konusu fonksiyonlar dikkate alındığında, dağıtım kanalında üyelerin fonksiyonların tamamı yerine belirli fonksiyonlarda uzmanlaşması daha yaygın olarak gözlemlenebilir.

Bütün pazarlama dağıtım sistemlerinin; ürünlerin değiş tokuşu, paranın değiş tokuşu ve bilginin değiş tokuşu olmak üzere üç temel işlevi yerine getirdiği söylenebilir. Ayrıca dağıtım kanallarının sırasıyla; fiziksel dağıtım, işlemleri kolaylaştırma ve iletişim işlevlerini de yerine getirdiği bilinmektedir (Webb, 2002). Dağıtım kanalları üzerindeki konsantrasyon, kar ve etkinliği artırmak üzerinedir (Lafferty ve Fossen, 2001). Rekabet gücünde ve karl1lıkta belirleyici olan dağıtım kanalının, pazarlamanın en belirleyici bileşeni olma özelliğinin giderek daha belirgin hale geldiği kabul edilmektedir (Buhalis, 2000b).

Pazar yapısındaki değişimler, dağıtım kanalı üyeleri arasında pazar gücünün kullanımı açısından önemli değişikliklere neden olabilmektedir (Granados, Kauffman, Lai ve Lin, 2011). Tüketim ya da kullanım için bir mal ya da hizmetin uygun olma sürecini içeren bir dizi bağımsız organizasyon olan dağıtım kanalının nihai amacı; doğru miktarda ve kalitede 
ürünün doğru yerde, doğru zamanda, doğru fiyata ve doğru müşteriye teslim edilmesidir (Buhalis, 2000a).

Endüstriyel mal üreten sektörlerde ürün, tüketicinin bulunduğu yere götürülmesine yönelik bir dağıtım sistemi uygulanırken, turizm sektöründe tam tersi bir uygulama ile tüketicinin turistik mal ve hizmetin bulunduğu yere ulaştırılmasıyla gerçekleşmektedir (Avcıkurt, Demirkol ve Zengin, 2009). Dolayısıyla, turizm sektöründe dağıtım pazardan üretim yerine yani tersine işleyen bir sistemdir.

Turizmde dağıtım kanalları; turizm paydaşlarının iletişimde bulunduğu ve ürünlerini pazarladıkları ağlardır ve bütün turizm ürün tedarikçileri ürünlerinin dağıtımı için pazarlamanın bir aşmasında bu kanallara bağımlıdır (Huang, Chen ve Wu, 2009). Tüm kanal işlerinin, kanal ortakları arasında verimli biçimde paylaştırılması ve yapılması önemlidir. Birden fazla kanalla çalışan bir şirketin, söz konusu kanalların hepsini benzer politikalarla işletmesi beklenir (Kotler, 2008). Üretici ve tüketici arasındaki bağlantılar, bir veya daha fazla aracı (örneğin, toptancılar, yurtiçi ve yurtdışı tur operatörler, perakendeci seyahat acentaları, bölgesel veya yerel turizm organizasyonları) yoluyla doğrudan ya da dolaylı olarak kurulabilir ve herhangi bir pazar ve destinasyonda farklı kanal yapıları dizisi oluşabilir. Doğrudan veya dolaylı satış tercihi ile uygun dağıtım kanalı seçimi, pazarın kapsamı ve dağıtımın maliyeti arasındaki ilişkiden büyük ölçüde etkilenebilmektedir. Sektörde büyük ölçekli turizm organizasyonlarının daha aktif ve açık dağıtım stratejilerine ve iyi gelişmiş pazarlama planlarına sahip oldukları görülmektedir (Mirzayeva, Sarışık ve Ekber, 2016).

Turizmde dağıtım kanalları ve kanal üyeleri arasındaki ilişkiler uzun zamandan beri araştırmalara konu olmaktadır. Turizm dağıtım kanalları, seyahat acentaları, global dağıtım sistemleri ve online rezervasyon sistemleri ile ilgilidir. Turizm destinasyonlarında acentalar talep tarafını, konaklama işletmeleri tedarikçi tarafını temsil etmektedir (Ivanov, Stoilova ve Illum, 2015). Her bir dağıtım kanalı üyesi ise diğer kanal üyelerinin davranışlarına bağımlıdır (Buhalis ve Laws, 2004) ve bu aktörler zincirleme olarak turizm hizmet bileşenlerini oluşturmaktadırlar (Mwesiumo ve Halpern, 2016). Turizm sektöründe dağıtım sisteminin yapısı sadece tüketicinin tercihlerini etkilememekte, aynı zamanda uygulanan iş modelleri ve pazarlama stratejileri de çeşitli kanal iştirakçileri tarafından işlere uyarlanmaktadır (Kracht ve Wang, 2010). Turizm dağıtım ağları, her bir organizasyonun katkı sağladığı ve yarattığ1 
toplam değeri paylaştığı karmaşık sistemler olarak yapılanmaktadır (Ford, Wang ve Vestal, 2012).

Turizm pazarlama aracıları dağıtım işlevini yerine getirmek suretiyle yer, zaman, bilgi ve miktar yararı ile değer yaratırlar. Kimi aracıların tüm dağıtım işlevleri, kimi aracıların ise daha sınırlı dağıtım işlevlerini yerine getirdiği görülmektedir. Turizmde pazarlama aracılarına turizm literatüründe seyahat aracıları da denilmektedir (Rızaoğlu, 2016). Turizm dağıtım kanalında yer alan aracıların, çeşitli fonksiyonları vardır ve bu fonksiyonların bazıları şu şekilde sıralanmaktadır (Cook, Hsu ve Marqua, 2016):

- Sunulan hizmetlerin çeşitleri ve mevcudiyetlerine ilişkin bilgi sağlamak,

- Rezervasyon ve diğer seyahat ayarlamaları yapmak,

- Biletleri hazırlamak ve / veya teyitlerini almak,

- Dağıtım kanallarının yeniden kullanılması için cesaretlendirmek,

- Mevcut ve potansiyel müşterilerle bağlantı kurmak,

- Yeni müşteri kazanma maliyetlerini düşürmek,

- Önceden satın alıp ya da rezervasyon yapıp münferit olarak ya da gruplara daha sonra satarak risk almak,

- Stok aşımlarını pazarlamak,

-Turizm hizmet sağlayıcılarına hedef müşteri davranışlarını kapsayan veri tabanı vasıtasıyla kapsamlı pazarlama verileri sağlamak.

Turizmde temel seyahat paketi, tur operatörü tarafindan sağlanan sadece ulaşım ve konaklamayı kapsar. Bu iki temel bileşen, tur operatörlerinin ve otellerin karşılıklı gelirlerini arttırarak, iş birliğini teşvik eden seyahat paketinin esasını oluşturmakta ve turistlerin paket tur seçimini etkilemektedir. Seyahat acentaları ile yapılan bu iş birliğii, otellerin satış ve pazarlama çabalarını genişleten en uygun maliyetli yol olarak görülmektedir(Guo ve $\mathrm{He}$, 2012). Turizm işletmeleri, turizm paketlerinin çok boyutlu doğasının ve çeşitliliğinin gerektirdiği şirketler arası iş birliğini artırmanın, sürdürülebilir turizm bölgelerini geliştirmenin ve devam ettirmenin, tedarik zincirinde rakiplerle, tedarikçilerle, müşterilerle ve şirketlerle iş birliği kurmanın ne kadar önemli olduğunun farkındadırlar (Guo ve He, 2012). İşletmeler ürünlerinin dağıtımı için alternatif kanalları dikkatle araştırdıkları ve mümkün olduğu kadar farklı kanal aracılarını kullanmayı tercih ettikleri görülmektedir. Dağıtım kanallarının sayısı ne kadar çok olursa işletmenin pazara erişimi de o oranda artacaktır 
(Bozkurt ve Demiral, 2014). Otellerin seyahat acentaları, online seyahat hizmet şirketleri, profesyonel konferans organizasyonları, kendi satış ekibi, otel resepsiyonu, rezervasyon çağrı merkezi, otel rezervasyon sistemleri ve online otel rezervasyon sistemleri gibi farkl1 pazarlama kanalları kullandıkları gözlenmektedir. Bu çoklu kanallar, bazen otel ile dağıtım kanalı arasında çatışmaya neden olsa da doluluk oranının yüksek olmasına imkan sağlar (Tan ve Dwyer, 2014). Otellerin çoklu dağıtım kanallarını, etki alanlarını ve pazar paylarını büyütmek ve maliyetlerini düşürmek için tercih ettikleri söylenebilir. Çoklu kanalların söz konusu pazar payını artırmaya yönelik etkisinin yanı sıra, farklı pazar bölümlerindeki çatışma nedeniyle, kanallardan biri satışları da düşürebilir. (Kang, Brewer ve Baloğlu, 2007).

\subsection{Turizm Dağıtım Kanallarında Çatışma}

Turizm örgütleri diğer paydaşların imkanlarından faydalanmak ve başarıya ulaşmak için tedarikçiler, rakipler, dağıtımcılar, yerel organizasyonlar, hükümet ve diğer şirketler gibi tüzel kişilerle yakın ilişkiler kurmaktadırlar. Bu ilişkilerin bazıları nispeten önemsizken, bazıları ise çok önemli olabilmektedir. Turizmde diğer paydaşlarla iş birliği ilişkisinin kurulması organizasyonun performansı ve devamlılığı için önemi artan hayati bir unsur olarak kabul edilmektedir (Guo ve He, 2012). Örneğin otellerin, tur operatörlerinin satış personeli ve başlangıç ödemesi gerektirmeyen ve sadece üretilen iş için ödeme yapılmasını sağlayan benzersiz avantajları fark etmesiyle, odalarını tur operatörleri aracılığı ile satmayı tercih ettikleri bilinmektedir. Ayrıca, operatörler otellerin stoklanamayan ürünlerini toptan satma yeteneğine sahiptir. Diğer taraftan oteller risklerinin bir bölümünü tur operatörlerine aktarmakta ve uzun dönemli planlar geliştirebilmektedirler. Tur operatörlerinin, otel gibi hizmet üreticilerinin tanıtım masraflarını düşürmelerine imkan sağladıkları bilinmektedir (Bastakis, Buhalis ve Butler, 2004). Konaklama işletmelerinin ürünlerini eş zamanlı birden çok dağıtım kanalı aracılığıyla satmaya başlaması, kanallarda yer alan aracıların aynı müşteriye rekabet ederek ulaşmasına da neden olmuştur. $\mathrm{Bu}$ durum bazı çatışmaları da beraberinde getirmiştir.

Yeni pazarlar ve yeni müşteriler elde etmek amacıyla, şirketler yeni dağıtım kanalları açmayı tercih etmektedirler (Tan ve Dwyer, 2014). Dağıtım kanalı aracıları üzerinden konaklama işletmelerine gelen müşteriler, genellikle toplam müşterilerin çoğunluğunu oluşturmaktadır (Kethüda ve Faikoğlu, 2017). Bu durum, bir pazarda aynı ürünün birden çok dağıtım kanalında farklı fiyatlarla satılarak kanalların çatışmasına sebep olabilir. Ayrıca kanal 
çatışması, bir kanal üyesinin diğer kanal üyelerini, amaçlarına ulaşmada engelleme ya da ket vurma davranışı içinde bulunmasıyla bağlantılıdır (Tan ve Dwyer, 2014). Araştırmacılar, tur operatörlerinin ya da seyahat acentalarının az sayıda şirketin hakim olduğu oligopol ve çok sayıda satıcıya karşılık az sayıda alıcının bulunduğu oligopson olarak çift taraflı bir güce sahip olduğunu vurgular (Ivanov, Stoilova ve Illum, 2015). Bu çift taraflı avantaj, seyahat acentalarına ve tur operatörlerine kuvvetli bir pazar gücü yaratarak otelcilerle yapılan görüşmelerde pazarlık etme avantajı sağlamakta ve böylece acentalar da konaklama tesisleri üzerinde, turizm dağıtım kanalında çatışmaya sebep olabilecek sıkı bir kontrol uygulayabilmektedirler.

Şirketler arası çatışmaları tetikleyen unsurları; firsatçı tavırlar, zorlayıcı talepler, haksızlık algısı ve ortağın performansından tatmin olmama şeklinde sıralamak mümkündür. Yine şirketler arası çatışmaların ön koşulları; salgın hastalık, siyasi istikrarsızlık, finansal krizler, terör saldırıları ve doğal felaketler gibi dış faktörler, dağıtım kanallarında dengesizlik, amaçların çatışması ve gerçeklik algısında farklılıklar olarak belirtilmektedir (Mwesiumo ve Halpern, 2016). Kanal çatışmalarıyla ilgili genel fikir birliği; çatışmaların ortadan kaldırılamayacağı, ancak yönetilebileceği şeklindedir. Yetersiz bir kanal çatışma yönetimi, satış firsatlarına, nihayetinde de kanal üyelerinin karlılığına zarar verebilir. Yaygın biçimde, pazarda kanalların çatışmasında üç temel noktadan bahsedilir ve bunlar; amaçların uyuşmaması, gerçeklikte farklı algılar ve benzer alanlarda faaliyet göstermek şeklindedir (Myung, Li ve Bai, 2009). Eğer pazar payında aşınma ve ürünün fiyatında düşüş meydana gelirse, kanal çatışması yıkıcı olabilir ve amaçların çatışması, kanalların çatışmasıyla sonuçlanabilir (Tan ve Dwyer, 2014). Küçük ve orta büyüklükteki turizm konaklama işletmeleri sıklıkla zayıf bir şekilde yönetilir ve pazarlanır. Çünkü bu işletmelerde kaynaklar genellikle uzmanlaşmış personel istihdamı ve tanıtım için yetersizdir. Bu açıdan konaklama işletmeleri dağıtım kanalı içindeki en zayıf bağlantıdır ve aracılara bağımlılıkları kaçınılmazdır (Bastakis, Buhalis ve Butler, 2004). Kanal çatışması, aynı markayı aynı ve müşteriyi takip eden mevcut kanallar tarafından pazarda yeni bir tür kanal devreye girdiği algılandığında ortaya çıkar. Bu kanallar oteller için ilave pazarlama araçları olarak rol oynarlar ve bu durum, otel gruplarında bütün aracılara eşit fiyatlandırma stratejisi uygulandığında bir sorun teşkil etmezken, farklı fiyatlar uygulandığında dağıtım kanalı aracıları arasında çatışma potansiyeli oluşturmaktadır (Tan ve Dwyer, 2014). 
Güç; kanal çatışmasını anlamada önemli bir kavramdır ve bağımlılığın kanal ilişkilerinde temel belirleyicisidir (Myung, Li ve Bai, 2009). Turizmde değer yaratılmasında ve ilişkilerin oluşturulmasında, genellikle iki organizasyondan bağımlı olanın dezavantajlı olduğuna inanılan bir güç dengesizliğinden bahsedilir (Ford, Wang ve Vestal, 2012). Tur operatörleri pazarın gücünü temsil eder ve kontrolleri altındaki pazar bölümü kısıtlayarak (Calveras ve Vera-Hernandez, 2005); pazarın merkezinde adil olmayan ticaret uygulamaları üretebilirler (Bastakis, Buhalis ve Butler, 2004). Özellikle gelişmekte olan ülkelerde turizm işletmelerinin, pazarı kontrol eden tur operatörleri tarafından şart koşulan durumları kabul etmek zorunda oldukları bilinmektedir (Andriotis, 2003). Seyahat acentaları ve tur operatörleri özellikle konaklama işletmeleri üzerinde baskın olmaları sonucunda isteklerini yaptırabilme gücünü elinde bulundurmaktadırlar. Her ne kadar kitle turizmi için gerekli olan toplu rezervasyonlar yaparak ve garantili satışlar yaparak konaklama işletmelerine finans açısından destek verseler de bu aracı işletmeler bazı durumlarda verdikleri sözleri yerine getirmemekte, bu da konaklama işletmelerinin maddi zarara uğramasına neden olabilmektedir (Mirzayeva, Sarışık ve Ekber, 2016). Tur operatörleri ve turizm tedarikçileri arasındaki görüşmeler aylar öncesinden başlamasına rağmen, otelciler ne kadar oda satılacağını kesin olarak bilmemektedirler. (Andriotis, 2003). Turizm dağıtım ağlarından simetrik olmayan güç nedeniyle, daha güçlü olan taraf daha zayıf olan ortağ tedarikçiyi değiştirmekle tehdit ederek, ürünü değerinden daha düşük bir miktara almaktadır. Bazı çatışmalar sağlıklı bir rekabet ortamı sağlamalarına rağmen, bazıları ise ortaklar arasında güveni yok ederek kanala zarar vermektedir (Ivanov, Stoilova ve Illum, 2015). Turizm organizasyonlarında güç bağımlılığı ilişkisi içinde bulunulduğu zaman, zayıf olan tarafın daha güçlü olan üye ile ortaklıktan daha az kazanacağına inanılır. Bu durum, daha zayıf olan organizasyona, diğer örgütlerin hassas kaynak ve bilgilerine bağlı olarak bir ikilem sunar. Bir taraftan, ortaklıkta zayıf olan taraflar güçlü olan ortağın sermayesine, kaynaklarına, pazarlarına ve bilgisine erişim olanağı bularak, büyük avantajlar elde ederken diğer taraftan, güçlü ortaklar organizasyon gücünü kullanarak toplam değer ilişkisinden kendi lehine keyfi pay ayırarak zayıf ortağın pazarlık etmesini imkânsız kılabilmektedir (Ford, Wang ce Vestal, 2012). Belirli bir dağıtım kanalı düzeyinde faaliyet gösteren bir şirketin ya da tüketicinin gücü, kanalın farklı alanlarında bulunan diğer üyelerin kararlarını etkileme kapasitesi ile değerlendirilebilir (Berne, Gonzalez ve Mugica, 2012). 
Turizm tedarik zincirinde ilişkiler yönlerine göre dikey ya da yatay olarak sınıflandırılır. Dikey ilişkiler; çıkarları birbirleri ile çatışmayan heterojen üyeler arasında mevcuttur (Zhang, Song ve Huang, 2009). Dikey kanal çatışması, örneğin bir otel işletmesi ve perakendeci seyahat acentası ya da seyahat toptancısı ve perakendeci seyahat acentası gibi dağıtım sisteminde farklı roller oynayan üyeler arasında meydana gelen çatışmadır. Örneğin, oteller seyahat toptancılarıyla hali hazırda devam eden bir iş birlikleri varken, kendi web siteleri aracılığıyla fiyat rekabetiyle sonuçlanacak şekilde satış yaptıkları zaman çatışma ortaya çıkabilir. Bu tarz bir çatışmada odalar için fiyat indirimi ve ilave tüketici menfaatleri sağlanabilir (Tan ve Dwyer, 2014). Yatay ilişkiler, tedarik zincirinin aynı düzleminde yer alan genellikle yeteneklerin çatıştı̆̆ homojen üyeler arasında bulunmaktadır. Benzer konaklama faaliyetini tedarik eden iki otel arasındaki ilişki yatay ilişki modeline bir örnektir (Zhang, Song ve Huang, 2009). Diğer bir kanal çatışma türü yatay kanal çatışması olarak adlandırılan çatışma türüdür. Turizm sektöründe benzer roller sergileyen kanal üyeleri arasında ortaya çıkan çatışma türüdür. Örneğin, perakendeci bir seyahat acentası başka bir seyahat acentası ile çatışma yaşayabilir ya da bir otel fiyat kırarak başka bir otelle çatışma yaşayabilir. Yatay çatışmalar bazen geleneksel seyahat acentaları ve online seyahat acentaları arasında da ortaya çıkabilir (Tan ve Dwyer, 2014).

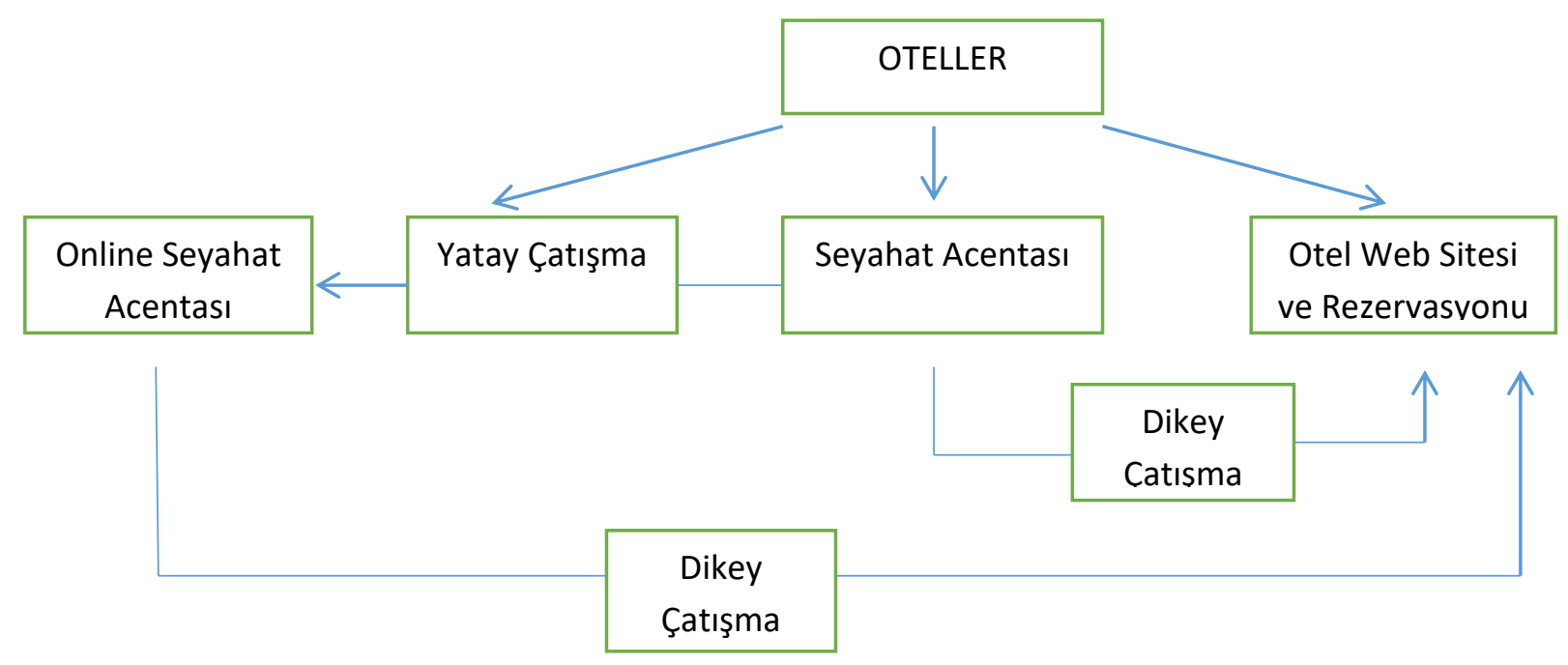

Şekil 1. Otel dağıtım kanalı ve potansiyel çatışma

Kaynak: Tan, J., ve Dwyer, L. (2014). Managing Distribution Channel Conflict in the Hotel Industry. International Journal of Marketing and Business Communication, 9-19. 
Kanal çatışmasının günümüzde otel operasyonlarını istila ettiği ve basit bir çözümünün olmadığı söylenebilir. Örneğin bir otel satış sürecini tamamen kendisi kontrol etmek isteyebilir ve bu durumda kesinlikle kanal çatışması olmayacaktır. Ancak, bu durumda otel işletmesinin pazarda yer alan tüketicilere ulaşması kısıtlanabilecektir. Diğer taraftan bir ürünün birçok kanal tarafından satılması, karlılığı düşürerek her birine pay ödenmesine neden olacaktır. Bu durum pazarda daha fazla tüketiciye ulaşmaya imkan verirken, daha az kontrola ve yönetilmesi gereken daha çok kanalla beraber karlılığın azalmasını neden olacaktır (Tan ve Dwyer, 2014). Konaklama sektöründe çok miktarda farklı fiyatlandırma stratejileri uygulanmaktadır. Oteller, kanal çatışmasını yönetmeye olanak sağlayacak stratejiler geliştirmelidirler. Kanal çatışması yıkıcı olduğunda, amaçlar saptanmalı ve çözüm yürürlüğe konmalıdır (Tan ve Dwyer, 2014). Karamustafa (2000) Pazar kanal ilişkileri üzerine yapmış olduğu çalışmada; Türkiye'nin konaklama operasyonlarını iyileştirmek için kendi kendine zarar vermesine neden olan iç faktörlere odaklanılmasının gerekliliğinden bahsetmiş ve bu faktörleri; odaların fazlalığı, zayıf yönetim becerileri, sadece birkaç turistik pazara yoğunlaşma ve nispeten biriyle benzer turistik ürünler sunma şeklinde belirtmiştir.

\section{YÖNTEM}

Türk turizminin şu an bulunduğu konuma gelmesinde en büyük rolün tur operatörlerine ait olduğu, özellikle Ege ve Akdeniz kıyı şeridi boyunca yer alan otel işletmelerinin uluslararası seyahat aracılarına bağımlılık düzeylerinin oldukça yüksek olduğu söylenebilir (Karamustafa, 2000). Türkiye'nin en çok turist ağırlayan destinasyonlarından iki tanesi olan Antalya ve Muğla ilimizi ziyaret eden turistlerin büyük çoğunluğunun dağıtım kanallarının ana aktörleri olan tur operatörlerinin düzenlediği charter uçak seferleri ile geldiği gözlemlenmektedir. $\mathrm{Bu}$ açıdan konaklama işletmeleri ile dağıtım kanalı aracıları tur operatörleri ve seyahat acentaları arasında yaşanan çatışmalar destinasyonların geleceği açısından çok önemlidir. Bu kapsamda konaklama işletmeleri yöneticilerinin bakış açısından konaklama işletmelerinin seyahat acentaları ve tur operatörleri ile yaşadıkları sorunlar ve çatışmalar tespit edilmesi amaçlanmıştır. Ülkemizdeki tüm otellere ulaşma imkanı zaman ve maliyet açısından kısıtlı olduğu için, tur operatörlerinin düzenlediği paket turlarla gelen kitlesel turizm faaliyetlerinin yoğun olması ve bu faaliyetlere ev sahipliği yapan konaklama işletmesi sayısının çok fazla olması nedeniyle Antalya'da faaliyet gösteren otellerin yöneticilerinin çalışmaya dahil edilmesine karar verilmiştir. Antalya İl Turizm Müdürlüğü ile irtibata geçilerek Antalya 
bölgesinde faaliyet gösteren 3 yıldız, 4 yıldız ve 5 yıldız oteller ile 1. sinıf tatil köylerini kapsayan tüm konaklama tesislerinin listesi çıkarılmıştır. Toplam 652 tesiste görev yapan yöneticilerden 426 tanesi araştırmaya katılarak anket doldurmuştur. Örneklem büyüklüğünün evreni temsil etme yeterliliğine sahiptir (Karagöz, 2019). Toplanan anketlerin tamamının analiz için uygun olduğu tespit edilmiş ve tamamı analize dahil edilmiştir. Ulaşılan yöneticiler seyahat acentaları ve tur operatörleri ile en fazla diyalog içerisinde olduğu var sayılan üst düzey yöneticiler, satış pazarlama yöneticileri ve önbüro yöneticileridir. Veri toplama aracı olarak anket kullanılmıştır. Ölçek hazırlanırken Ivanov, Stoilova, ve Illum (2015) tarafından geliştirilen ölçek Türkçe'ye çevirisi yapılarak kullanılmış ve araştırmacılar tarafından seyahat acentaları ve konaklama tesisleri arasında ortaya çıkan çatışmalar için çözüm önerilerine yönelik açık uçlu bir soru eklenerek yöneticilerin bireysel fikirlerine de ulaşılmaya çalışılmıştır. Hazırlanan anket 1 Temmuz ve 30 Ekim 2018 tarihlerinde uygulanmıştır. Verilerin normal dağılım gösterip göstermediğini belirlemek için basıklık ve çarpıklık değerleri incelenmiştir. Basıklık ve çarpıklık değerleri $-1,50$ ve $+1,50$ aralığında olduğundan verilerin normal dağıldığı belirlenmiştir. Bu doğrultuda verilerin analizi için parametrik testlerden tek yönlü varyans analizi (ANOVA) ve betimleyici analizler yapılmıştır.

\section{BULGULAR}

Çalışmada öncelikle katılımcıların demografik özelikleri, turizm sektöründe geçirdikleri süre ve deneyimleriyle beraber konaklama işletmeleriyle ilgili bulgulara yer verilmiştir. Tablo 1 'de konaklama işletmeleri ve bu işletmelerin yöneticilerine ilişkin betimleyici istatistikler yer almaktadir.

Tablo 1. Konaklama işletmeleri ve yöneticilere ilişkin betimleyici istatistikler

\begin{tabular}{llcc}
\hline \multicolumn{1}{c}{ Değişkenler } & Gruplar & $\boldsymbol{n}$ & Yüzde \% \\
\hline \multirow{2}{*}{ Cinsiyet } & Kadın & 96 & 22,5 \\
& Erkek & 330 & 77,5 \\
\hline \multirow{2}{*}{ Medeni durum } & Evli & 285 & 66,9 \\
& Bekar & 141 & 33,1 \\
\hline \multirow{3}{*}{ Yaş } & $19-34$ yaş aralığında & 95 & 22,3 \\
& $35-49$ yaş aralığında & 282 & 66,2 \\
& 50 yaş ve üzeri & 49 & 11,5 \\
\hline \multirow{2}{*}{ Eğitim düzeyi } & Lise & 35 & 8,2 \\
& Önlisans & 64 & 15,0 \\
& Lisans & 277 & 65,0 \\
\multirow{2}{*}{ Tesisteki pozisyonu } & Lisansüstü & 50 & 11,7 \\
& Üst Düzey Yönetici & 151 & 35,4 \\
& Satış Pazarlama Yöneticisi & 190 & 44,6 \\
\hline Mevcut tesisteki çalışma Süresi & Ön Büro Yöneticisi & 85 & 20,0 \\
\hline & 1 ylldan az & 54 & 12,7
\end{tabular}




\begin{tabular}{|c|c|c|c|}
\hline & $\begin{array}{l}1-3 \text { yil } \\
4-6 \text { y1l } \\
7-9 \text { y1l } \\
10 \text { yil ve üstü }\end{array}$ & $\begin{array}{l}154 \\
101 \\
33 \\
84 \\
\end{array}$ & $\begin{array}{c}36,2 \\
23,7 \\
7,7 \\
19,7 \\
\end{array}$ \\
\hline \multirow{4}{*}{ Sektör tecrübeleri } & $1-3$ y1l & 5 & 1,2 \\
\hline & 4-6 y1l & 14 & 3,3 \\
\hline & $7-9$ y1l & 34 & 8,0 \\
\hline & 10 yll ve üstü & 373 & 87,6 \\
\hline \multirow{4}{*}{ Tesisin türü } & 3 yıldız & 3 & 0,7 \\
\hline & 4 Yildız & 37 & 8,7 \\
\hline & 5 yıldız & 364 & 85,4 \\
\hline & 1. sinif tatil köyü & 22 & 5,2 \\
\hline \multirow{4}{*}{ Tesisin faaliyet yılı } & $1-3$ y1l & 36 & 8,5 \\
\hline & 4-6 y1l & 58 & 13,6 \\
\hline & $7-9$ y1l & 46 & 10,8 \\
\hline & 10 yll ve üstü & 286 & 67,1 \\
\hline \multirow{4}{*}{ Acentaya bağımlılık düzeyi } & $\% 0-50$ & 53 & 12,4 \\
\hline & $\% 51-70$ & 39 & 9,2 \\
\hline & $\% 71-90$ & 115 & 27,0 \\
\hline & $\% 91-100$ & 219 & 51,4 \\
\hline \multirow{5}{*}{ Acenta ile sorun yaşama sıklığı } & Hiçbir Zaman & 5 & 1,2 \\
\hline & Bazen & 144 & 33,8 \\
\hline & Nadiren & 162 & 38,0 \\
\hline & S1klıkla & 106 & 24,9 \\
\hline & Her Zaman & 9 & 2,1 \\
\hline
\end{tabular}

Tablo 1'e göre; katılımcıların \% 77,50'si erkek ve \% 22,5'i kadındır. Bu noktada konaklama işletmelerinde erkek yöneticilerin üst düzey yönetici olarak tercih edildiği söylenebilir. Katılımcıların \% 69'u evli ve \% 33,1'i bekardır. Yöneticilerin \% 66,2'sinin 35 - 49 yaş aralığında olduğu belirtilebilir. Katılımcılar eğitim düzeyi açısından incelendiğinde \% 15 'inin ön lisans, \% 65'inin lisans ve \% 11,7'sinin lisansüstü ve \% 8,2'sinin lise mezunu olduğu belirlenmiştir. $\mathrm{Bu}$ noktada konaklama işletmelerinde üst düzey yöneticilerin çoğunlukla üniversite mezunlarından oluştuğu söylenebilir.

Araştırmaya katılanların \% 44,6'sı satış pazarlama yöneticisi, \% 35,4'ü üst düzey yönetici ve \% 20'si ise ön büro yöneticisidir. Yöneticiler tesiste çalışma süresi açısından incelendiğinde \%36,2'si 1-3 y1l arası, \% 23,7'sin ise 4-6 y1l şeklindedir. Katılımcıların \%87,6's1 ise 10 yıl ve üzerinde sektör tecrübesine sahiptir. Yöneticilerin çalıştıkları tesis türü dağılımında ise \% 85,4'ü tatil köyü şeklindedir. Tesislerin \% 67,1'i 10 y1l ve üzerinde faaliyet göstermektedir. İşletmelerin \% 12,4'ü \% 50'den az bağımlılık olduğunu belirtirken \% 87,6'sı bağımlılık düzeyinin \% 50'den fazladır. Acenta ile sorun yaşama sıklığına bakıldığında ise dağılım \% 1,2 si hiçbir zaman, \% 33,8'i bazen, \% 38'i nadiren \% 24,9'u sılklıla ve \% 2,1'i her zaman 
olarak belirtilmiştir. Konaklama işletmelerinin yöneticilerinin bakış açısından seyahat acentalarıyla yaşanan çatışmalar Tablo 2'de gösterilmektedir.

Tablo 2. Konaklama işletmelerinin yöneticilerinin bakış açısından seyahat acentalarıyla yaşanan çatışmalar

\begin{tabular}{|c|c|c|c|c|}
\hline & \multirow[b]{2}{*}{$\overline{\mathbf{x}}$} & \multirow[b]{2}{*}{ SS } & \multicolumn{2}{|c|}{ F Değerleri } \\
\hline & & & $\begin{array}{c}\text { Faaliyet } \\
\text { Yılı }\end{array}$ & $\begin{array}{c}\text { Acenta } \\
\text { Bağımlılığı }\end{array}$ \\
\hline \multicolumn{5}{|l|}{ Çatışma Kaynakları } \\
\hline Olumsuz kontrat maddeleri & 3,52 & 1,167 & 1,205 & 1,025 \\
\hline $\begin{array}{l}\text { Seyahat acentalarının kendi çıkarlarını kontratta kendi lehlerine } \\
\text { tek taraflı olarak korumaları }\end{array}$ & 3,88 & 1,226 & 0,652 & 0,855 \\
\hline Kontratta yer alan fiyatlar & 3,05 & 1,258 & 0,562 & 1,533 \\
\hline Kontratta yer alan komisyon oranları & 3,18 & 1,317 & 0,394 & 1,542 \\
\hline $\begin{array}{l}\text { Seyahat acentasının talep ettiği fiyat ile otelin hizmet kalitesi } \\
\text { arasındaki uyumsuzluk }\end{array}$ & 3,78 & 1,218 & 1,128 & 0,448 \\
\hline Kontratta belirtilen release süreleri & 2,91 & 1,347 & 1,150 & 0,453 \\
\hline $\begin{array}{l}\text { Kısa release sürelerinin kullanılmayan odaların satışına yeterli } \\
\text { süre vermemesi }\end{array}$ & 3,08 & 1,369 & 0,794 & 0,772 \\
\hline $\begin{array}{l}\text { Kötü bir sezonda seyahat acentasının gelecek dönemler için } \\
\text { pazarlık yapması }\end{array}$ & 3,87 & 1,314 & 2,048 & 1,440 \\
\hline $\begin{array}{l}\text { Seyahat acentalarının kontratta yer alan sorumluluklarını yerine } \\
\text { getirmemesi }\end{array}$ & 3,45 & 1,257 & 1,509 & 0,931 \\
\hline Seyahat acentalarının müşteriyi yanlış bilgilendirmesi & 3,69 & 1,277 & 1,709 & 0,133 \\
\hline Seyahat Acentaları tarafından geç bildirilen oda listeleri & 3,70 & 1,257 & 1,536 & 0,714 \\
\hline $\begin{array}{l}\text { Seyahat acenteleri tarafindan değiştirilmiş müşteri memnuniyeti } \\
\text { anketleri }\end{array}$ & 3,01 & 1,381 & 0,930 & 2,481 \\
\hline Seyahat acentalarının iptal şartlarına uymamaları & 3,66 & 1,219 & 1,213 & 1,182 \\
\hline Seyahat acentalarının zamanında ödeme yapmaması & 4,11 & 1,167 & 1,645 & 0,092 \\
\hline Seyahat acentasının borcunu ödememesi & 3,86 & 1,305 & 2,600 & 0,863 \\
\hline Bölgede az sayıda seyahat acentasının hakim olması & 2,95 & 1,439 & 0,560 & 0,931 \\
\hline \multicolumn{5}{|l|}{ Yöneticiler Açısından Seyahat Acentalarının Rolü } \\
\hline $\begin{array}{l}\text { Turistleri yönlendirmede seyahat acentaları önemli bir role } \\
\text { sahiptir. }\end{array}$ & 4,36 & ,991 & 0,311 & 1,820 \\
\hline $\begin{array}{l}\text { Tesislerin gelişmesinde seyahat acentaları önemli bir role } \\
\text { sahiptir. }\end{array}$ & 3,91 & 1,156 & 1,436 & 1,751 \\
\hline $\begin{array}{l}\text { Taşımacılıkta ve günü birlik turlarda seyahat acentaları önemli } \\
\text { bir role sahiptir. }\end{array}$ & 4,15 & 1,075 & 0,898 & 1,700 \\
\hline $\begin{array}{l}\text { Fiyatların belirlenmesinde seyahat acentaları önemli bir role } \\
\text { sahiptir. }\end{array}$ & 3,68 & 1,222 & 0,297 & 0,784 \\
\hline \multicolumn{5}{|l|}{ Pazarlık Gücü } \\
\hline Konaklama işletmesinin pazarlık gücü & 3,17 & 1,030 & $3,376^{*}$ & 1,743 \\
\hline Seyahat acentasının pazarlık gücü & 3,99 & ,915 & $3,323^{*}$ & 1,512 \\
\hline Konaklama işletmesinin seyahat acentalarına bağımlılığ1 & 4,17 & ,924 & $3,552^{*}$ & $5,626^{* *}$ \\
\hline \multicolumn{5}{|l|}{ Çatışma İçin Geliştirilen Çözümler } \\
\hline Karşı tarafın şartlarını kabul etmek. & 2,86 & 1,311 & 0,121 & 0,840 \\
\hline Her iki tarafı da tatmin edecek bir çözüm bulmak. & 3,45 & 1,003 & 1,546 & 2,614 \\
\hline Karşı tarafa kendi şartlarını dayatmaya çalışmak. & 3,41 & 1,187 & 1,275 & 0,109 \\
\hline Sözleşmeyi feshetmek. & 1,99 & 1,100 & 0,229 & $4,562^{* *}$ \\
\hline \multicolumn{5}{|c|}{ 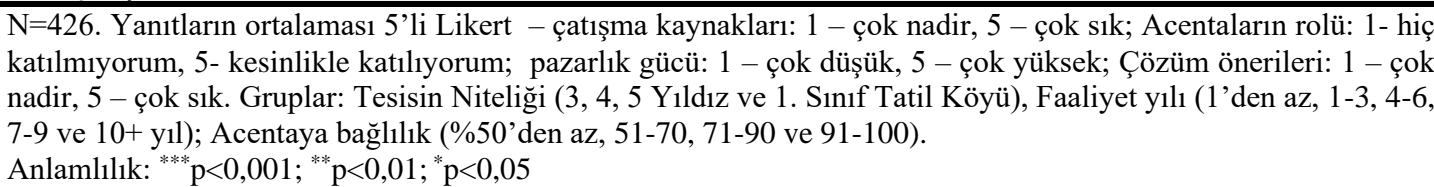 } \\
\hline $\begin{array}{l}\text { Not: Anova testinde varyansların eşitliği varsayımı să̆landı̆̆ } ~ \\
\text { ise Tamhane testi kullanılmıştır. }\end{array}$ & la & effe & ăglan & durumlardo \\
\hline
\end{tabular}


Yapılan tek yönlü varyans analizi (ANOVA) sonucunda faaliyet yılı açısından pazarlık gücüne ilişkin verilen yanıtlarda anlamlı farklılıklar olmuştur. Otellerin sektördeki faaliyet yılları azaldıkça bu tesislerde çalışan otel yöneticilerinin değerlendirmelerine göre; otellerin pazarlık gücü düşükken, seyahat acentalarının pazarlık gücü ise daha yüksek düzeyde olmaktadır. Yine faaliyet yılı azaldıkça bu tesislerde çalışan otel yöneticileri konaklama tesislerinin seyahat acentalarına bağımlılı̆̆ını daha yüksek seviyede değerlendirmektedir. Acenta ile çalışma oranları nispeten daha az olan konaklama işletmelerinde yöneticilerin, konaklama tesislerinin acentalara bağımlılı̆̆ı ile ilgili değerlendirmeleri daha düşük seviyededir. Sözleşmenin feshedilmesi ile ilgili çözüm önerisini uygulayan işletmeler ele alındığında, acenta ile çalışma oranı yükseldikçe bu işletmelerde çalışan yöneticilerin bu çözüm önerisini uygulama sıklığının düştüğü görülmektedir. Tablo 3'te konaklama işletmelerinin ve acentalar arasındaki çıkan çatışmalara yönelik çözüm önerileri yer almaktadır.

Tablo 3. Konaklama işletmelerinin ve acentalar arasındaki çıkan çatışmalara yönelik çözüm önerileri

\begin{tabular}{ll}
\hline IFADE & N \\
\hline Karşılık anlayış ve ortak çözüm, etik ilkelere bağlılık & 115 \\
$\begin{array}{l}\text { Acentalar ve oteller yaptıkları anlaşmalara bağlı kalmalı ve müşteriye doğru bilgi } \\
\text { aktarmalı }\end{array}$ & 48 \\
Yabancı acenta bağımlılığı düşürülmeli & 28 \\
Tesis yatırımlarının oranının belli bir seviyede tutulması & 18 \\
Destinasyon pazarlamasının etkin yapılması & 16 \\
Turizme yönelik yasa ve yönetmelikle anlaşmaların denetlenmesi & 15 \\
Acenta komisyon oranlarının standartlaştırılması & 14 \\
Doğrudan pazarlama faaliyetleri (telefon, online vb.) ile müşteri bulmanın belli bir & 13 \\
orana çıarılması & \\
Oteller açısından hizmet kalitesinin arttırılması & 8 \\
Konaklama işletmelerinin müşteri sadakati oluşturması & 7 \\
Ulusal tur operatörlerinin artmasının sağlanması & 4 \\
Çözüm yok & 4 \\
Anlaşmalarda nitelikli personellerin olması & 4 \\
Uzun dönemli otel-acenta anlaşmaları yapılmalı & 2 \\
Doluluk oranının arttırılması ve Avrupa pazarını büyütmek & 1 \\
\hline
\end{tabular}

Tablo 3'e göre; konaklama işletmelerinin ve acentalar arasındaki çıkan çatışmalara yönelik çözüm önerilerinde, en fazla karşılıklı anlayışla ortak çözüm ve etik ilkelere bağlı1ığın olması vurgulanmıştır. Aynı zamanda anlaşmaya bağlılık ve müşteriye doğru bilgi aktarımı konusu üzerinde de durulmuştur. Yöneticiler tarafından en az önerilen çözümler ise uzun dönemli anlaşmaların yapılması, doğrudan pazarlama faaliyetlerinin arttırılması, müşteri sadakatinin oluşturulması ve ulusal tur operatörlerinin artması olarak belirtilmiştir. Oteller ve acentalar 
arasında çıkan çatışmalara yönelik yöneticilerin ifade ettiği bazı çözüm önerileri şu şekilde ifade edilmiştir:

- Acenta komisyon oranlarının standart olmasi gerekmektedir, otellerin online ya da telefonla satışlarını \%30'ların üzerine çıkarması acenta bă̆ımlılı̆̆ını azaltacaktır. Tesisleşmenin arz-talep dengesi gözetilerek yavaşlatılması (devlet kontrolünde olabilir) ve tarafsı bir kurum tarafindan otel ve acenta antlaşmaları denetlenmesi birçok sorunu çözebilir.

- Acentalar son yıllarda pazarlık güçlerini iyice arttırdılar ve sektörün kötüye gittiği durumları kullanarak otelcileri zor duruma düşürmektedirler. Bu tip durumların önüne geçmek için belli bir seviyede acenta komisyonları tutulmalıdır.

- Antalya bölgesinde otellerin acente kontratlar haricinde kendi satış pazarlama faaliyetlerini yapma becerisi genel olarak gelişmiş değil ve bu yüzden bu pazarlama biçimi gelişmediği için maalesef acentelere sıkı sıkıya bir bă̆ımlılık söz konusu. Böyle bir bă̆ımlılık olduğuna göre; kontrat aşamasında otelleri istemedikleri şartlara zorlamaktadırlar. Otellerin farklı pazarlama kanalları ile acenta bağımlılı̆̆ını azaltmast ve acentaları komisyon oranlarının belli bir standarda tabi tutulması gerekir.

- Şeffaf ve her iki tarafinda çıkarları gözetilerek çalışılmalıdır. Özellikle dış pazarda acenteler istedikleri indirimi alana kadar rezervasyonları ellerinde tutuyorlar örneğin $\% 5$ - \%10 gibi indirimler onaylandı̆̆ a anda 150 odayı aynı anda gönderiyor. Bu tarz etik dışı davranışlar yaşandiğı sürece anlaşmazlıklar devam edecektir. Karşılıklı çıkarlar gözetilerek etik ilkelere bağlı kalınması sağlanırsa sorun da oluşmaz.

\section{SONUÇ VE ÖNERILER}

Kitle turizminin yoğun olduğu Antalya bölgesindeki konaklama tesislerinin yöneticileriyle yürütülen bu çalışma sonucunda, yöneticilerden elde edilen veriler doğrultusunda konaklama tesislerinin yüksek düzeyde seyahat acentalarına ve tur operatörlerine bağımlı olduğu sonucuna ulaşılmıştır. Bu durum literatürle benzerlik gösterse de (Andriotis 2003; Buhalis, 2000), literatürde çevrim içi rezervasyon olanaklarının artması nedeniyle daha az bağımlılığın olduğunu tespit eden çalışmalarda yer almaktadır (Berne vd., 2012; Ivanov vd., 2015). 
Bağımlılık düzeyinin artması konaklama tesisleri seyahat acentaları arasında her zaman bir sorun olarak ortaya çıkmamaktadır.

Otellerin faaliyet sürelerinin azaldıkça seyahat acentalarına ve tur operatörlerine olan bağımlılığın arttığı ve bunun bir sonucu olarak konaklama tesislerinin pazarlık gücünün azaldığı ulaşılan bir diğer sonuçtur. Konaklama işletmelerinin seyahat aracıları ile çalışma düzeylerinin azalması ise bu durumla doğru orantılı olarak bağımlılığı da azaltmaktadır. Aynı şekilde bir konaklama işletmesi ne kadar fazla oranda seyahat acentası ile çalışıyorsa o düzeyde bağımlılığı artmakta ve bir tehdit olarak ortaya çıkmaktadır. Ayrıca seyahat acentaları ile çalışma oranı yükseldikçe sözleşmenin feshedilmesi bir seçenek olmaktan çıkmaktadır. Yöneticilerin sektördeki tecrübe yılı, eğitim düzeyi ve işletmede sahip oldukları pozisyon arasında ise doğru orantı olduğu söylenebilir.

$\mathrm{Bu}$ çalışma kapsamında konaklama işletmeleri ve acentalar arasındaki çatışmaları azaltmak için konaklama tesislerinin tur operatörlerine ve seyahat acentalarına bağımlılığ düşürülmelidir. Bu kapsamda doğrudan pazarlama, internet üzerinden pazarlama, telefon ve web siteleri aracılığıyla pazarlama uygulamaları yürürlüğe konabilir. Yeni konaklama yatırımları yerine var olan tesislerin doluluklarını arttıracak farklı düzenlemeler yapılabilir. Acenta sözleşmelerinde komisyon oranları standart hale getirilebilir. Doluluk oranlarını arttırmak adına farklı pazarlara ve farklı turizm türlerine yönlenebilir. Özellikle kriz dönemlerinde arz güvenliği açısından farklı pazarlama kanalları tercih edilmelidir. Hizmet kalitesi arttırılarak müşteri sadakati oluşturulmalıdır. Daha sonraki çalışmalarda farklı destinasyonlarda ve özel ilgi turizm türlerine göre dağıtım kanallarında yaşanan çatışma nedenleri ve çözümleri belirlenebilir. Ayrıca seyahat acentalarının bakış açısından dağıtım kanallarında yaşanan çatışmalar incelenebilir. Otellerin gelirlerinde seyahat acentalarının rezervasyonlardaki paylarına göre farklılıklar olup olmadığını belirlemeye yönelik çalışmalar yap1labilir.

\section{KAYNAKÇA}

Andriotis, K. (2003). Dependency on Tour Operators - Problem Faced by Cretan Tourism Bussinesses and the Views of Their Owners/Managers. International Journal of Hospitality and Toursim Administrarion, 4(3), 23-48.

Avcıkurt, C., Demirkol, Ş., \& Zengin, B. (2009). Turizm İşletmelerinin Pazarlanmasında 7P Ve 7C. İstanbul: Değişim Yayınları. 
Bastakis, C., Buhalis, D., \& Butler, R. (2004). The Perception Of Small and Medium Sized Tourism Accommodation Providers on the Impacts of the Tour Operators' Power in Eastern Mediterranean. Tourism Management, 25(2), 151-170.

Berne, C., Gonzalez, M. G., \& Mugica, J. (2012). How ICT Shifts The Power Of Tourism Distribution Channels. Tourism Management, 205-214.

Bozkurt, M., \& Demiral, Ö. (2014). Pazarlama Karması: Dağıtım. Meslek Yüksek Okulları İçin Pazarlama içinde, (ed. M. Bozkurt). İstanbul: Paradigma Akademi Yayınları.

Buhalis, D. (2000)a. Marketing the Competitive Destination of the Future. Tourism Management, 21(1), 97-116.

Buhalis, D. (2000)b. Relationships in the Distribution Channel of Tourism: Conflict Between of Hoteliers and Tour Operators in the Mediterranean Region. International Journal of Hospitality \& Tourism Administration, 1(1), 113-139.

Buhalis, D., \& Laws, E. (2004). Tourism Distribution Channels. London: Thomson Learning.

Calveras, A., \& Vera-Hernandez, M. (2005). Quality Externalities Among Hotel Establishments: What is the Impact of Tour Operators. Tourism Economics, 11(4), 571-593.

Cook, R., Hsu, C., \& Marqua, J. (2016). Tourism The Business of Hospitality and Travel. Ankara: Nobel Akademik Yayıncılık Eğitim ve Danışmanlık.

Ford, R., Wang, Y., \& Vestal, A. (2012). Power Asymmetries in Tourism Distribution Networks. Annals of Tourism Research, 39(2), 755-779.

Granados, N., Kauffman, R., Lai, H., \& Lin, H.-c. (2011). Decommodiztization, Resonance Marketing, and Information Technology: An Emprical Study of Air Travel Service Amid Channel Conflict. Journal of Management Information Systems, 28(2), 39-74.

Guo, X., \& He, L. (2012). Tourism Supply-Chain Coordination: The Cooperation Between Tourism Hotel and Tour Operator. Tourism Economics, 18(6), 1361-1376.

Güreş, N. (2008). Dağıtım Kanallarında Çatışma Nasıl Önlenebilir? Mustafa Kemal Üniversitesi Sosyal Bilimler Enstitüsü Dergisi, 5(9), 227-241.

Hacıoğlu, N. (2014). Turizm Pazarlaması. Ankara: Nobel Akademik Yayıncılık Eğitim ve Danışmanlık .

Huang, L., Chen, K.-H., \& Wu, Y.-W. (2009). What Kind Of Marketing Distribution Mix Can Maximize Revenues: The wholesaler Travel Agencies' Perspective. Tourism Management, 30(5), 733-739.

Ivanov, S., Stoilova, E., \& Illum, S. F. (2015). Conflict Between Accomodation Establishment and Travel Agencies. Tourism and Hospitality Research, 15(1), 54-70. 
Kang, B., Brewer, K. P., \& Baloğlu, S. (2007). Profitability and Survivalibity of Hotel Distribution Channels. Journal of Toursim \& Travel Marketing, 22(1), 37-50.

Karagöz, Y. (2019). SPSS ve AMOS uygulamalı nitel-nicel-karma bilimsel araştırma yöntemleri ve yayın etiği. Ankara: Nobel Akademik Yayıncılık.

Karamustafa, K. (2000). Marketing-channel Relationships: Turkeys Resort Purveyors' Interactions with International Tour Operators. Cornell hotel and restaurant administration quarterly, 41(4), 21-31.

Kethüda, Ö., \& Faikoğlu, Ş. (2017). Dağıtım Kanalı Türlerinin Otellerin Cirosuna ve Doluluk OranınaEtkisinin Değerlendirilmesi: Akçakoca'da Bir Araştırma. Bartın Ünivesitesi İktisadi ve İdari Bilimler Fakültesi Dergisi, 8(15), 203-224.

Kotler, P. (2008). A'dan Z'ye Pazarlama. İstanbul: Kapital Medya Hizmetleri A.Ş.

Kracht, J., \& Wang, Y. (2010). Examining the Tourism Distribution Channel: Evolution and Transformation. International Journal of Contemporary Hospitality Management, 736-757.

Lafferty, G., \& Fossen, A. V. (2001). Integrating Tourism Industry: Problems and Strategies. Tourism Management, 22(1), 11-19.

March, R., \& Wilkinson, I. (2009). Conceptual Tools For Evaluating Tourism Partnerships. Tourism Management, 30(3), 455-462.

Mirzayeva, G., Sarışık, M., \& Ekber, Ş. (2016). Otel İşletmelerinin Dağıtım Kanalı Seçimindeki Davranışları: Bakü'deki Otel İşletmelerinde Bir Araştırma. ASSAM International Refereed Journal, 3(6), 21-32.

Mwesiumo, D., \& Halpern, N. (2016). Interfirm Conflicts in Toursim Value Chains. Tourism Review, 259-271.

Myung, E., Li, L., \& Bai, B. (2009). Managing The Distribution Channel Relationship With EWholesalers: Hotel Operators' Perspective . Journal of Hospitality Marketing \& Management, 18(8), 811-828.

Pearce, D. (2008). A Need-Function Model Of Tourism Distribution. Annals of Tourism Research, 35(1), 148-168.

Pearce, D. (2009). Channel Design For Effective Tourism Distribution Strategies. Journal of Travel \& Tourism Marketing, 26(5-6), 507-521.

Rızaoğlu, B. (2016). Turizm Pazarlaması. Ankara: Detay Yayıncılık.

Stangl, B., Inversini, A., \& Schegg, R. (2016). Hotels' Dependency On Online Intermediaries And Their Chosen Distribution Channel Portfolios: Three Country Insights. International Journal Of Hospitality Management, 52, 87-96. 
Tan, J., \& Dwyer, L. (2014). Managing Distribution Channel Conflict in the Hotel Industry. International Journal of Marketing and Business Communication, 3(1), 9-19.

Webb, K. L. (2002). Managing Channelsof Distribution in the Age of Electronic Commerce. Industrial Marketing Management, 31(2), 95-102.

Zhang, X., Song, H., \& Huang, G. Q. (2009). Tourism Supply Chain Management: A New Research Agenda. Tourism Management, 30(3), 345-358. 